\title{
Shanghai Secondary Housing Purchases Restriction Analysis
}

\author{
Shibo Zhou ${ }^{1, \text { a }}$, Yimin Xue ${ }^{2, b}$ \\ ${ }^{1}$ College of Liberal Arts and Sciences, Arizona State University, Tempe 85281, US; \\ ${ }^{2}$ College of Finance and Statistics, Hunan University, Changsha 410006, China. \\ ashibozh94@sina.com, bxyimin@hnu.edu.cn
}

Keywords: Housing policy, housing price, government intervention.

\begin{abstract}
Shanghai governments announced new Secondary Housing Purchases Restriction policy in March 2016 for controlling the extreme high housing price. The source of market failure is that the housing is a merit good, everyone needs a house for shelter. The objectives of these policies are welfare and equity, where trade-off of liberty. Low to middle income local families are the main stakeholders that support the policy, while real estate investors, wealthy families, and non-local residents oppose the policy. However, after the policies released, the housing price was keeping increasing in few months. Therefore, our finding is that only does the government release the circulation of lands and increase the development of low-rent housing, the supply can be elastic in the long term.
\end{abstract}

\section{Introduction}

According the Ricardian equivalence theory, large number economists believe that government policy do not impact market price well. Because this theory says government policies do not affect aggregate consumption because consumers anticipate that they have to re-pay the addition government stimulus and reduce private consumption to save for the anticipated future tax increase. Do government policies affect the real estate by housing policy?

Housing policy which is the fundamental justification for government intervention in real estate market, based on the market characteristics such as externalities, monopoly power and misinformation [1]. Housing price is not like stock price, which functions as the random walking path. In the housing market, unprofessional and irrational consumers dominate demand and price [2]. Clayton (1997) found that rapid increasing of hosing price has a significant relationship with the irrational investment. Hence the price bubbles exist in most of the housing markets, including Shanghai [3]. When the real estate market is out of control by itself, the government will use the 'invisible hand' as a regulator. In the past, most paper analysed the effect of monetary policy on housing price. The effect of quantitative monetary policies on Chinese housing price are significant. While pricing instruments on housing as the real interest rate cannot significantly affect housing market [4]. The land policy is often introduced into housing market as well. In early 2004, in order to cooling the housing market, the government issued a series of policies which summarized: "tight management of land, strict supervision of credit”. The local governments were asked to tighten their land supply, so that to regulate the housing industry [5].

This article discusses the Shanghai Secondary Housing Purchases Restriction particularly. In March 2016, Shanghai's Ministry of Housing and Urban-Rural Development, along with three other government departments, announced a series of policies that restricted housing purchases in the city. From the figure 1, it is obvious that the Shanghai housing price continuous increasing recent years. And the peak value goes up to around $80,000 \mathrm{RMB}(\mathrm{US} \$ 11,500)$ per square meter in inner ring area. However, the 2016 Shanghai average monthly income is 6,504 RMB(US\$944) [6], which the average housing price pre-square meter is ten times than the average monthly income. Therefore, 
the policies aimed to control the extremely high and rising prices in the city's real estate market by reducing demand [7].

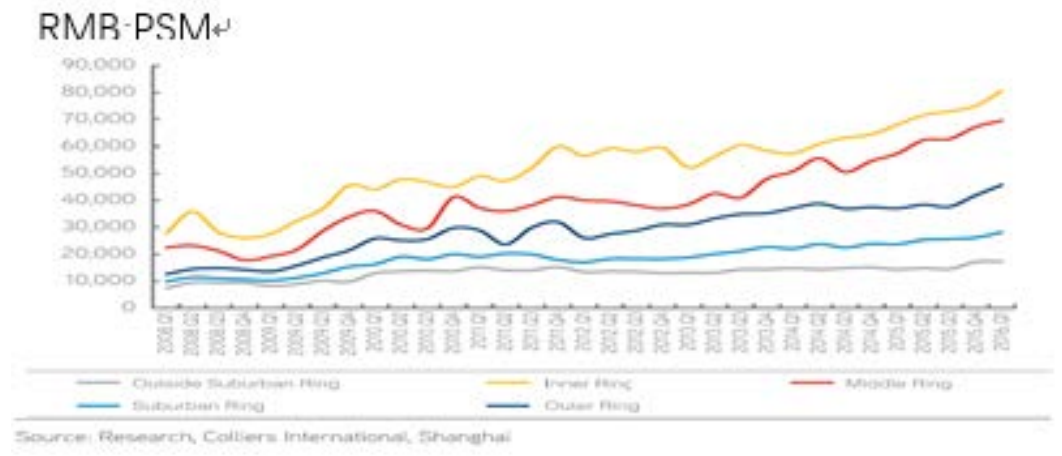

Figure 1 Shanghai Average Residential Sales Price by Area

The source of market failure that justified further government intervention in Shanghai's real estate market was the perception that housing is a merit good. The merit good is a good or service which a society deems should be provided on the basis of need, rather than ability to pay. Everyone needs a house for shelter. Shanghai, the biggest city in China with, nearly 15 million people which make a large demand on housing market. And in China, the government owns all the land. The local government essentially has a monopoly in the real estate market. Therefore, the house price is higher than the equilibrium. This was facing a situation in which low- and moderate-income families could not afford a home, meanwhile, rich people are willing to buy more than one house.

There are two main provisions of the new policy governing housing purchases (summarized by Table 1 and Table 2). First, the minimum down payment for purchase of a second home was increased from $40 \%$ to $50 \%$ of the purchase price if the house was defined as a normal home (personal living space). For commercial sites, the minimum down payment increased to $70 \%$. Second, the government established stricter requirements for non-local residents who are buying their first house. Previously, non-local buyers only needed to show proof of payment of tax or social insurance for three continuous years. Under the new policy, non-local residents are asked to provide five years' tax or social insurance certificates before they may purchase a home. Both policies are designed to reduce the demand (and lower prices) in the real estate market [8].

Table 1 Changes to Down Payment Policy for Second Homes

\begin{tabular}{|c|c|c|}
\hline & Previous Policy & New Policy \\
\hline $\begin{array}{c}\text { Minimum Down Payment for } \\
\text { Ordinary Homes Using } \\
\text { Commercial Loan: }\end{array}$ & & $50 \%$ \\
\hline $\begin{array}{c}\text { Minimum Down Payment for } \\
\text { Non-Ordinary Homes Using } \\
\text { Commercial Loan: }\end{array}$ & $40 \%$ & $70 \%$ \\
\cline { 3 - 3 }
\end{tabular}

Table 2 Changes to Minimum Payment Period for Taxation or Social Insurance

\begin{tabular}{|c|c|}
\hline Previous Policy & New Policy \\
\hline Two of the previous three years & Five consecutive years \\
\hline
\end{tabular}

\section{Policy Impact}

\subsection{Policy Objectives}

The major policy objectives of the Shanghai intervention in the housing market are welfare and equity. Welfare is defined as the assurance that the population's basic needs are satisfied. Housing is a basic need. The housing policy aims to improve the ability of low-and moderate-income 
families to purchase homes, thereby increasing their welfare. Since Chinese land market is monopoly, the higher prices give rise to deadweight loss on social welfare. Through this policy, the housing demand for rich non-local residents will decrease and social welfare will enlarge. The policy also addresses vertical equity, which involves unequal treatment of people in different classes. Wealthy and non-local residents are restricted from owning as many homes as they wish, so that low income families can purchase housing.

\subsection{Tradeoff}

The policy represents a trade-off of liberty for welfare and equity. Liberty is the freedom to do or act as one chooses without causing harm to others. It can be said that the policy curtails the freedom of wealthy and non-local residents by limiting their ability to own as many homes as they wish. As such, restricting housing is an affront to individual liberty.

\section{Key Stakeholders}

\subsection{Two Groups}

Low to middle income families are the main stakeholders that support the policy, while real estate investors, wealthy families, and non-local residents oppose the policy. The two groups differ primarily in their view of the policy objectives. The supporters of this policy (low and middleincome families) will have increased chances to own homes, therefore enhancing their welfare. The groups opposed to the policy view it as unfair. The wealthy non-local residents thought they should be treated horizontal equally as local families. They are opposed to the government's control of the sector, which is likely to lead to a reduced ability to purchase homes. This may lead to reduce incomes for investors who want to own more houses and sell extra at higher price in the future [9].

\subsection{Supporters' Tools of Policy Discourse}

Supporters of the restrictive housing policies tell a narrative of helplessness and control. They believe that housing prices in the city have been out of control. The government must intervene to control so that housing is accessible for lower and middle-income families.

Supporters use both symbolic and numeric devices to promote their narrative. The notable stylistic device used by supporters is metaphor. For example, they refer to an "over heated market" and welcome the efforts of the government to "cool" or "reign in" housing costs. [9] The metaphors compare that the demand of Shanghai real estate market increases too much. It is like high temperature needed to cool down or like a high-speed horse should be decreased. Supporters also employ numbers to simplify a complex problem. For example, "New home prices rose $2.9 \%$ last month from January, closely trailing Shenzhen where the average cost of new homes climbed 3.9\% month on month". [9] These accurate numbers indicate that the housing price in Shanghai is continuous increasing and stays in very high level.

\subsection{Opponents' Tools of Policy Discourse}

On the other side, opponents, tell a narrative of decline, namely that change is only an illusion. They argue that the policy changes may decrease the demand in the luxury homes market, but housing prices will still remain high. The real problem is the limited supply of land for buildings. [9]

Opponents also use both symbolic and numeric devices to promote their narrative. For example, they talk about a "land king". A "land king" is a developer who paid the highest record price for a parcel of land. "With all the competition, once a developer successfully bids for a plot, he is likely to exit the game for a while. Then those who failed to win land will pursue the next site until they finally get one". Therefore, the extremely high prices limit developers' access to land. The 'land king' is metaphor for the winner [10]. Numerical data have also been used to support the narrative. Opponents argue that the residential land supply is small, just 24 percent of the annual supply plan [10]. These data are intended to show that the low supply of land in the real estate market is the underlying problem. 


\section{Policy Enforcement}

\subsection{Policy Solutions}

This rule is one type of policy enforcement mechanism where official mandates regarding behaviour are enforced through the justice system. Previously, non-local buyers only needed to show proof of tax payment or social insurance for three continuous years. Under the new policy, non-local residents are asked to provide five years of tax receipts or social insurance certificates before they may purchase the second home. This is a precise rule. It is transparent and objective which helps people understand the new policy accurately and makes enforcing the policy easier.

Negative inducement, the sanctions for non-compliance, is the other enforcement mechanism. The minimum down payment for the purchase of a second home was increased. The higher down payment acts as a penalty for second home buyers because it will make these buyers unhappy. Chen Zhiyi, a Jiangsu province resident working in Shanghai, said that "it is unfair that the city needs us to work for its prosperity but bars us from buying properties.” [9]

\subsection{Unintended Consequence}

There exists an unintended consequence. Under the new policies, a family buying a second home is required to pay $50 \%$ of the down payment while the first-time buyer just needs to pay only $40 \%$ [11]. If some couples have already owned a house and really want to purchase the second one with lower price, they have to legally split up to satisfy the new policy. This is called nominal divorce or "fake divorce." After the divorce, one of the couple could then pay the reduced $10 \%$ down payment [11]. To deal with this situation, Shanghai's government has announced there will be a new policy imposed shortly to prevent the fake divorces.

\section{Policy development and analysis}

In this part, we discuss about the efficiency of the policy and its development. In China, the real estate market often an increase of sales in August and September annually because most building are ready for sale at that time. After we remove this volatility, the sold property price, area and amount increased continuously. Also from figure 2 and 3, in the long term, the housing price in Shanghai reach the peak in the six years. It seems that the secondary housing purchase restriction does not restrict the increasing price. Based on principles in the theory of elasticity, the supply of the housing market lack elasticity in the short term. So policy instruments mainly contribute to demand and expected value of housing in the short term. Shanghai Secondary Housing Purchases Restriction aims to inhibit the demand and to control the housing price. However, this policy appears to have little effect. From the demand and supply curves of figure 4, when supply is inelastic, the price will decline with the decrease of demand. In fact, the price of housing increases continuously. It is not feasible for the government to control the demand and remain the total of supply unchanged at the same time. Citizens have a rigid demand on housing, which rely on consumption level and supply of land.

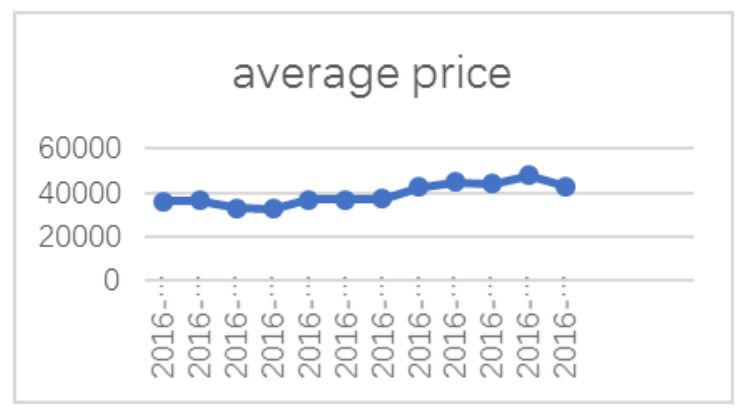

Figure 2 Shanghai Average Residential Sales Price $\left(\mathrm{RMB} / \mathrm{m}^{2}\right)$ 


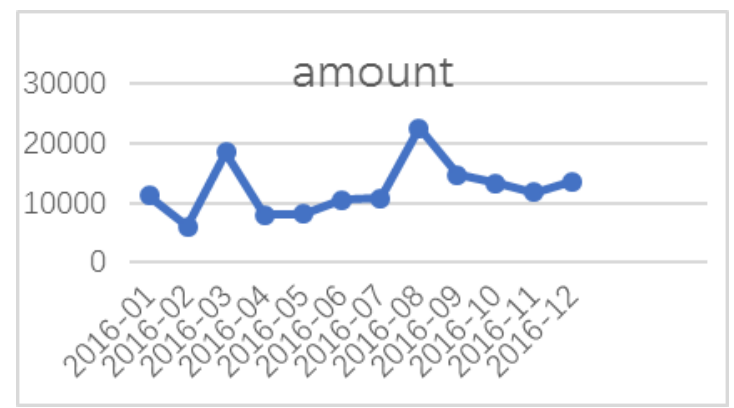

Figure 3 Amount of sold apartments in Shanghai

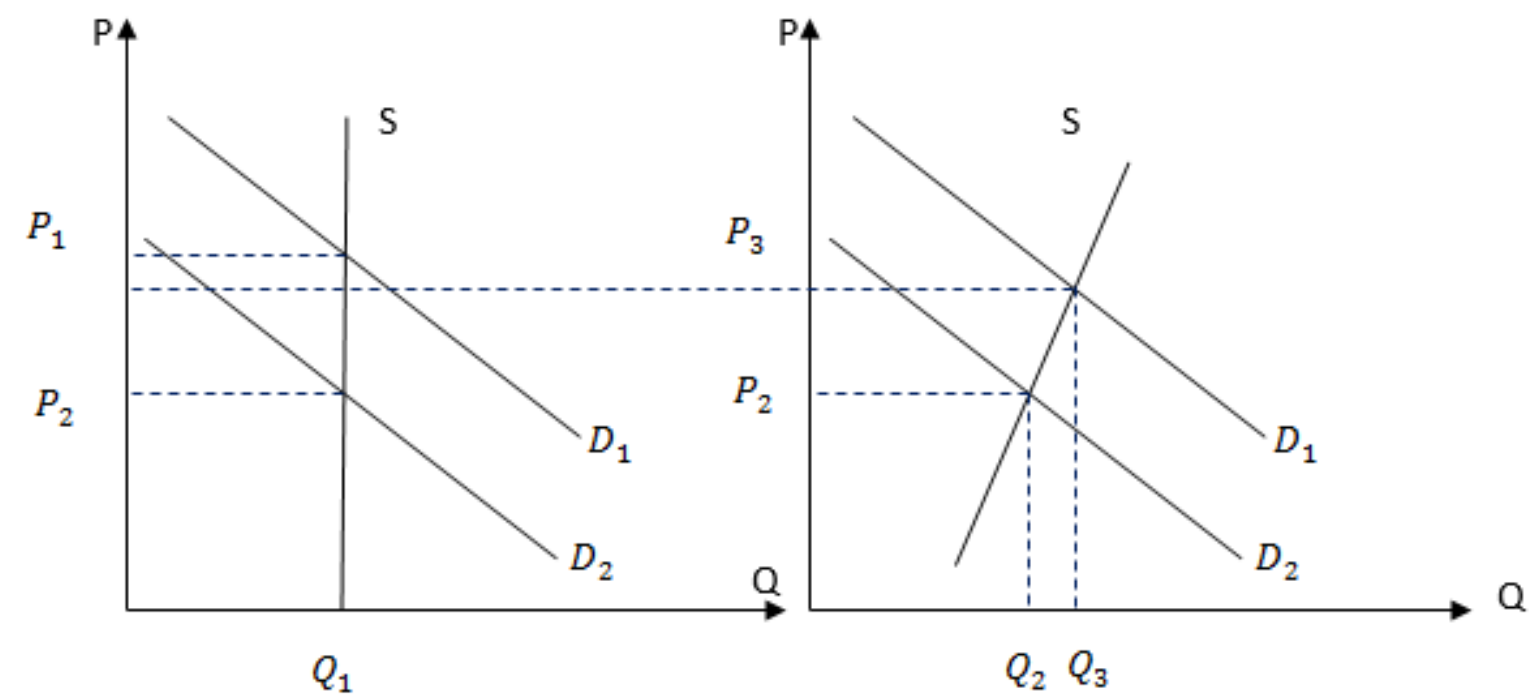

Figure 4 Demand-Supply Curve

\section{Conclusion}

Compared to other countries, Chinese government should release restrict the supply of landing and allow free trade of landing in order to restrain housing price from rising too fast. As $\mathrm{Yu}$ [12] analysed in his essay, government housing policy announcements do not have statistically significant influence on housing market, which may cause big shock in the housing market. The shock in the housing market appears in the short-term supply and demand. However, the affect does not conform to the government.

Only does the government release the circulation of lands and increase the development of lowrent housing, the supply can be elastic in the long term. Under this assumption, the housing price will increase less and the demand will reach the equilibrium that can offer more housing. The similar conclusion was confirmed in the essay written by lieming Zhu [13]. It said that government intervention instruments only serve as catalysts which work together with other right ingredients. However, it is still unclear how the policy will affect housing market in the long term. Therefore, we need to keep paying attention on subsequent developments.

\section{Reference}

[1]. Yang Zan, and Jie Chen. Housing affordability and housing policy in urban China. Heidelberg: Springer, 2014,87:1-3

[2]. Yang Gnag, Wang Hongwei, Wang Zhengzheng. Different Types of Monetary Policy Instruments and Regional Housing Prices: A Comparative Study on the Influences of Regulation in China [J]. Shanghai Jiaotong Univ. (Sci.), 2016, 21 (3): 343-349

[3]. Dayong Zhang, Ziyin Liu, Gang-Zhi Fan. Price bubbles and policy interventions in the Chinese 
housing market. [J] Journal of Housing \& the Built Environment. 2017 32:133-155

[4]. Clayton, J. Are housing price cycles driven by irrational expectations? Journal of Real Estate Finance and Economics, 1997,14 (3), 341-363

[5]. Deng, L., Q. Shen, and L. Wang. "The Emerging Housing Policy Framework in China." Journal of Planning Literature 26, no. 2 2011: 168-83. doi:10.1177/0885412210390220.

[6]. Wang Qingchu, ‘Average salary of Shanghai employees up 9.5\% in 2016,'Shanghai Daily, 6th April 2017, http://www.shanghaidaily.com/metro/Average-salary-of-Shanghai-employees-up-95-in2016/shdaily.shtml

[7]. 'Shanghai Makes Changes to Housing Policy,' Colliers International, 29th March 2016, http://www.colliers.com/en-gb/china/about/media/2016-03-29-shanghai-housing-policy.

[8]. Cherry Cao, 'Shanghai Unveils Tightening Policy for Home Market,' Shanghai Daily, 25th March 2016, http://www.shanghaidaily.com/business/Shanghai-unveils-tightening-policy-forhome-market/shdaily.shtml.

[9]. Daniel Ren, 'Shanghai tightens rules on buying second homes to cap soaring property prices,' South China Morning Post, 25th March 2016, http:/www.scmp.com/news/china/policiespolitics/article/1930551/shanghai-tightens-rules-buying-second-homes-cap-soaring

[10]. Zheng Yang Peng, "Lag in supply, ample liquidity drive Shanghai’s sizzling land sales,” South China Morning Post, 23rd August 2016, http://www.scmp.com/property/hong-kong-china/article/20 07412/lag-supply-ample-liquidity-drive-shanghais-sizzling-land

[11]. Dominique Fong, Junya Qian and Yifan Xie, "In Shanghai, Couples Rush to Divorce to Buy Property Later,” The Wall Street Journal, 29th August, 2016, http://blogs.wsj.com/chinarealtime/20 16/08/29/in-shanghai-couples-rush-to-divorce-to-buy-property-later.

[12]. Yu, H. J., \& Lee, S. (2010). Government housing policies and housing market instability in Korea. Habitat International, 34 (2), 145-153.

[13]. Zhu, J. (1997). The effectiveness of public intervention in the property market. Urban Studies, 34, 627-646. 